\title{
Sustainable Development of "Green" Technologies: Legal Protection of the Ambient Air from Pollutants
}

\author{
Larysa Soroka
}

Ph.D. in Law, Associate Professor, Scientific Institute of Public Law

(Kyiv, Ukraine)

E-mail: 1soroka_kw@ukr.net

https://orcid.org/0000-0002-6979-6049

\section{Olena Syntichenko}

Ph.D. in Law, Associate Professor, Kyiv National University of Trade and Economics

(Kyiv, Ukraine)

E-mail: elena.sitnichenko@ukr.net

https://orcid.org/0000-0002-9740-0216

The evolution of technology is heading for "green" technologies that are safe for the environment. In the scientific community, various conceptual models are developed that are based on the aerospace activities of humanity for the purpose of exploration and use of the aerospace environment (Sky, Space) for survival and development. In the paper, the authors consider an important component of conceptual models of aerospace environment exploration, that is, preservation and restoration of the natural state of ambient air under intensive development of road and aerospace transport. The authors will analyze the legal acts of Ukraine and the European Union that regulate the protection of ambient air from pollutants in exhaust gases of road and aerospace transport, as well as emphasize the search for ways to improve the legislative framework in this area.

Keywords: ambient air, pollutants, ecological quality, legal regulation, aerospace activities, road and aerospace transport

Received: March 21, 2018; accepted: April 27, 2018

Advanced Space Law, Volume 2, 2018: 70-75.

https://doi.org/10.29202/asl/2018/2/9

(C) Soroka, Larysa, 2018

(C) Syntichenko, Olena, 2018 


\section{Problem Statement}

Sergey Krichevskiy, a recognized researcher in space exploration technologies, argues that the technologies evolve towards "green" technologies, that is, safe for the environment [Krichevskiy, 2015]. He proposed a conceptual model of "cosmic dream" based on the aerospace activities of humanity for the purpose of exploration and use of aerospace space (Sky; Space) for survival and development [Krichevskiy, 2017]. In the article, the authors consider an important component of Krichevskiy's conceptual model, that is, preservation and restoration of the natural condition of ambient air under intensive development of road and aerospace transport. The authors focus on the legal framework of the European Union and Ukraine that regulates motor vehicle emission into the ambient air.

The Basic Law of Ukraine formulates and provides for the right to preserve and restore the natural state of the ambient air, to create favorable conditions for life, to ensure air quality and to prevent the hazardous effects of the ambient air on human health and the environment. Article 16 of the Constitution of Ukraine states that ensuring environmental quality and maintaining ecological balance throughout Ukraine, overcoming the aftermath of the Chornobyl catastrophe, and preserving the gene pool of the Ukrainian people is a duty of the State [Constitution, 1996]. The State implements this function through the protection of the ambient air from the harmful effects of pollutants from exhaust gases of motor vehicle and aerospace technology [Krichevskiy, 2015].

The implementation of the Association Agreement between Ukraine and the European Union, including the compliance with the norms and standards of the European Union in various areas, is relevant today. It is related to carrying out the necessary reforms in Ukraine, involving environmental protection.

The ambient air is an essential physical and biological factor for human existence and a source of life on Earth that in its natural state is composed of a mixture of gases, such as nitrogen (over 78\%), oxygen (about 20\%), as well as argon, carbon dioxide, hydrogen, helium, neon, ozone, dust, water vapor and some other substances [Kyshko-Yerli, 2014]. Scientific and technological progress has expanded the use of atmospheric resources and properties. However, the negative anthropogenic impact on the ambient air has been increasing significantly. The scale of its industrial pollution has threatened the human health, the ozone layer, weather and climate of our planet.

The aim of the article is to analyze the legal regulations of Ukraine and the EU on the issues of ambient air protection from exhaust emission pollutants of road and aerospace transport, as well as to find ways to improve the legislative framework in this area.

\section{Main research areas}

With the advent of the objective need to protect the atmosphere and to create technical means of such protection and control of pollution, international law began to form bans on transboundary air pollution. In November 1979, a multilateral Convention on Longrange Transboundary Air Pollution was adopted that became a significant achievement in international legal regulation of transboundary pollution. The Convention came into force on March 16, 1983. The parties to the agreement are most European countries including Ukraine, Belarus, Canada and the United States. 
However, European governments did not develop a system of measures to improve environmental security until early 90's of the last century. Manufacturers of automotive and aerospace engineering were obliged to improve gradually their products in order to reduce harmful exhaust gas emission.

In 2000, Ukraine acceded to 1958 "Agreement concerning the adoption of uniform technical prescriptions for wheeled vehicles, equipment and parts which can be fitted and/ or be used on wheeled vehicles and the conditions for reciprocal recognition of approvals granted on the basis of these prescriptions" [Agreement, 2000]. Since then in Ukraine, the issue of environment-friendly transport is being considered seriously. The document provides an effective mechanism for the gradual introduction of modern road and aerospace transport requirements in Ukraine that comply with EU standards.

In the countries of the European Union, one of the main regulatory acts on the concept of "exhaust gas pollutants from vehicles" is Regulation (EC) No 715/2007 of the European Parliament and of the Council of the European Union of 20 June 2007 "On type approval of motor vehicles with respect to emissions from light passenger and commercial vehicles (Euro 5 and Euro 6) and on access to vehicle repair and maintenance information" [Regulation, 2008]. Article 3 of the Regulation defines the basic concepts in the area regulated. For example, the concept "gaseous pollutants" is considered as the exhaust gas emissions of carbon monoxide, nitrogen oxides, expressed in nitrogen dioxide (NO2) equivalent, and hydrocarbons.

In the current legislation of Ukraine, the concept of "pollutant" is defined as a substance of chemical or biological origin that is present in or enters the ambient air and can have a negative impact on the human health and environment directly or indirectly [On Protection, 1992].

A widespread approach to the above-mentioned concept is provided in the Modern Ecological and Environmental Dictionary, which defines pollutants as "natural or humanmade physical agents, chemicals that enter the environment or occur therein in excess of the limits of normal fluctuations or average natural background over a certain period or are therein in excess of the indicators acceptable for specific purposes" [Dictionary, 2010: 25].

Therefore, the norms of exhaust gas pollutants from road and aerospace transport are the maximum permissible amount of pollutants released into environment that have a negative impact on it.

The legal framework of State standards for ambient air protection from the adverse impact of pollutants is the Law of Ukraine "On Environmental Protection" [Law, 1992]. The specified law provides for the requirements of environmental quality of road and aerospace transport, obligatory for enterprises, institutions, organizations that carry out design, manufacture, operation, maintenance of motor vehicles, aircraft, vessels, other mobile means and installations, production and supply of fuel.

Under these requirements, the entities, engaged in road and aerospace transport, are subject to:

1. To develop and implement a complex of measures for reducing toxicity and elimination of pollutants contained in emissions and discharges of road and aerospace transport;

2. To shift to less toxic types of energy, fuel;

3. To adhere to the operating mode of road and aerospace transport;

4. To implement other measures aimed at preventing and reducing emissions and discharges into environment;

5. To adhere to the established levels of physical influences (Part 1 of Article 56 of this Law). 
Moreover, the heads of road and aerospace transport organizations and the owners of road and aerospace transport are responsible for complying with the standards of permissive limit of emissions and discharges of pollutants and permissive limit levels of physical environmental impacts established for the respective type of vehicle (Article 33 of this Law) [Law, 1992].

To ensure environmental protection, to promote a better quality of life, to prevent negative effects of the ambient air on the human health and environment, to regulate emissions of the most common and hazardous pollutants, the Main principles (strategy) of the State environmental policy of Ukraine for the period until the year 2020 [On the main, 2011] have been adopted.

The most common and hazardous pollutants to be regulated include nitrogen oxides, benzo[a]pyrene, dioxide and other sulphur compounds, carbon monoxide, ozone, suspended solids (micro particles and fibers), lead and its compounds, formaldehyde, metals and their compounds, organic amines, volatile organic compounds, persistent organic compounds of chlorine, bromine and their compounds, fluorine and its compounds, cyanides, freons, arsenic and its compounds.

To assess air pollution, the air quality standards and emission standards for the maximum permissible air pollutants, the levels of hazardous effects of physical and biological factors within the localities, recreation zones, other places of residence, permanent or temporary stay of people, environmental objects are established [On procedure, 2002].

The procedure for the development and approval of these averages is regulated by the Resolution of the Cabinet of Ministers of Ukraine No. 303 of March 13, 2002 [On approval, 2001]. The standards are developed for each type of mobile source newly created and/or operated throughout Ukraine, taking into account the requirements of national and international legislation on environmental protection.

For road and aerospace transport operated, standards are developed considering existing technologies, and for newly created, considering the most advanced technologies available for reducing pollutants in exhaust gases, the effect of physical factors of mobile sources and purifying exhaust gases. The standards are developed in accordance with the Instruction on general requirements for the development of standards for pollutants in exhaust gases and the effect of physical factors of ambient air pollution mobile sources, which is approved by the Ministry of Environment and Natural Resources of Ukraine.

The UNECE Regulations and the State Standards of the SSU regulate the level of pollutants in exhaust gases of road and aerospace transport. These standards are developed to form a regulatory framework for controlling environmental indicators of operation of road and aerospace transport that use conventional or alternative fuels in their propulsion system, and black smoke from road and aerospace transport with diesel engines and gas diesel engines. The requirements of road and aerospace transport environmental standards meet the requirements of the European Union Directive 96/96 / EC "On the approximation of the laws of the Member States relating to roadworthiness tests for motor vehicles and their trailers" [Regulation, 2007].

The standards for the maximum permissible pollutant concentrations in the environment and the level of hazardous physical and biological effects on it are uniform throughout Ukraine. These standards are determined according to the scheme approved by the Ministry of Ecology and Natural Resources of Ukraine in order to comply with the requirements of the national legislation and legislation of the European Union. 


\section{Conclusions}

The authors have found that most discrepancies with European environmental practices are in the organization and implementation of monitoring of the ambient air. It should be noted that the air quality monitoring system in Ukraine was developed and implemented more than half a century ago; most of the air quality monitoring stations were established in the 40-50s of the $20^{\text {th }}$ century.

The reform of the monitoring system can solve the problem of limited awareness of communities, as well as authorities, on the state of the environment, including the use of web technologies. In the course of reforming the State environmental monitoring system, the continuity of environmental components monitoring, the maximum use of existing monitoring structures, as well as the optimization of funding for maintaining the operation and development of the monitoring system, should be ensured.

In this regards, a key reform is the implementation of Directive 2008/50/EC, which provides for the establishment of zones and agglomerations according to the degree of air pollution, the development of air quality action plans for zones and agglomerations where levels of pollutants exceed limit values or targets, short-term action plans for zones and agglomerations where there is a risk of exceeding the limits of pollution, monitoring of dust content (PM2.5 and PM10) and other pollutants in the air.

Therefore, the analysis of current efforts to harmonize domestic environmental protection practices on ambient air quality and standards of the European Union reveals that the complexity of the problems and the lack of established mechanisms for regulating ambient air quality, which would ensure its predicted quality and compliance with environmental standards, create obstacles to the further harmonization of environmental legislation, and establish non-compliance with the requirements of the European law on environmental protection [Directive, 2008].

\section{[ㅁ] References}

Dyrektyva 2008/50/IeS Yevropeiskoho Parlamentu ta Rady vid 21 travnia 2008 roku "Pro yakist atmosfernoho povitria ta chystishe povitria dlia Yevropy” vid 21.05.2008 № 2008/50/IeS. http://zakon5.rada.gov.ua/laws/show/994_950 (in Ukrainian)

Konstytutsiia Ukrainy. Vidomosti Verkhovnoi Rady Ukrainy, 1996. № 30.- st. 141. (in Ukrainian)

Krichevskiy, Sergey. Evolution of Technologies, "Green” Development and Grounds of the General Theory of Technologies. Philosophy and Cosmology, 2015 (Vol.14): 119-138.

Krichevsky, Sergey. Cosmic Humanity: Utopia, Realities, Prospects. Future Human Image, 7 , 2017: 50-70.

Kyshko-Yerli, O.B.Adaptatsiia ekolohichnoho zakonodavstva Ukrainy do prava navkolyshnoho seredovyshcha Yevropeiskoho Soiuzu. Chasopys Kyivskoho universytetu prava. 3, 2014: 215-219. (in Ukrainian)

Pro zatverdzhennia pereliku naibilsh poshyrenykh $i$ nebezpechnykh zabrudniuiuchykh rechovyn, vykydy yakykh $v$ atmosferne povitria pidliahaiut rehuliuvanniu. Postanova Kabinetu Ministriv Ukrainy vid 29 lystopada 2001 r. N 1598. http://search.ligazakon. ua/1_doc2.nsf/link1/KP011598.html. (in Ukrainian) 
Pro osnovni zasady (stratehiiu) derzhavnoi ekolohichnoi polityky Ukrainy na period do 2020 roku. Zakon Ukrainy vid 21 hrudnia 2010 r. №2818-6. Vidomosti Verkhovnoi Rady Ukrainy. 2011. № 26. st.218. (in Ukrainian)

Pro okhoronu atmosfernoho povitria: Zakon Ukrainy vid 16 zhovtnia 1992 r. №2707-12. Vidomosti Verkhovnoi Rady Ukrainy. 1992. № 50. St.678. (in Ukrainian)

Pro Poriadok rozroblennia ta zatverdzhennia normatyviv ekolohichnoi bezpeky atmosfernoho povitria. Postanova Kabinetu Ministriv Ukrainy vid 13 bereznia 2002 roku № 299. Ofits. visn. Ukrainy. 2002. № 12. St. 571. (in Ukrainian)

Rehlament (IeS) №715/2007 Yevropeiskoho Parlamentu ta Rady YeS “Pro zatverdzhennia typu kolisnykh transportnykh zasobiv stosovno shkidlyvykh vykydiv lehkykh pasazhyrskykh transportnykh zasobiv ta transportnykh zasobiv komertsiinoho pryznachennia (Ievro-5 ta Yevro-6) i pro dostup do informatsii shchodo remontu ta tekhnichnoho obsluhovuvannia kolisnykh transportnykh zasobiv" vid 20 chervnia 2007 r. Ofitsiinyi visnyk Yevropeiskoho Soiuzu vid 31.07.2008. (in Ukrainian)

Slovnyk-dovidnyk suchasnykh ekolohichnykh ta pryrodookhoronnykh terminiv. Ukl. Honcharenko H.Ie., Sovhira S.V. Kyiv: Naukovyi svit, 2010. (in Ukrainian)

Uhoda pro pryiniattia yedynykh tekhnichnykh prypysiv dlia kolisnykh transportnykh zasobiv, predmetiv obladnannia ta chastyn, yaki mozhut buty vstanovleni ta/abo vykorystani na kolisnykh transportnykh zasobakh, i pro umovy vzaiemnoho vyznannia ofitsiinykh zatverdzhen, vydanykh na osnovi tsykh prypysiv. Vid 10.02.2000. http://zakon2.rada. gov.ua/laws/show/995_343 (in Ukrainian)

Regulation (EC) No 715/2007 of the European Parliament and of the Council of 20 June 2007 on type approval of motor vehicles with respect to emissions from light passenger and commercial vehicles (Euro 5 and Euro 6) and on access to vehicle repair and maintenance information. http://eur-lex.europa.eu/legal-content/EN/TXT/ HTML/?uri=URISERV:128186\&from=DE

Zakon Ukrainy "Pro okhoronu navkolyshnoho pryrodnoho seredovyshcha". Vidomosti Verkhovnoi Rady Ukrainy. 1992. № 41. St.546. (in Ukrainian) 